Jurnal Psikologi Teori dan Terapan

2016, Vol.7, No. 1, 1-8, ISSN: 2087-1708

\title{
Self Esteem dan Self Disclosure Pada Mahasiswa Psikologi Pengguna Blackberry Messenger
}

\author{
Ferdiana Suniya Prawesti ${ }^{1}$, dan Damajanti Kusuma Dewi \\ Program Studi Psikologi Universitas Negeri Surabaya
}

\begin{abstract}
The purpose of this research is to determine the correlation between self esteem and self disclosure of Psychology students of Universitas Negeri Surabaya who are using a social network of blackberry messenger. This research used quantitative method with correlational research design. Participants in this research were 187 students of Psychology students who have blackberry messenger accounts and are active users of blackberry messenger. Data collected using self esteem and self disclosure scales and analyzed using product moment correlation. The result shows that the coefficient correlation is 0,315 in the significant level 0,000 ( $p>0,05)$, which means that hypothesis of this research "there is correlation of self esteem and self disclosure to the Psychology students of Universitas Negeri Surabaya who are using a social network blackberry messenger" is accepted.
\end{abstract}

Keywords: Self esteem, self disclosure, blackberry messenger

\begin{abstract}
Abstrak: Penelitian ini bertujuan untuk mengetahui hubungan self esteem dengan self disclosure mahasiswa Psikologi Universitas Negeri Surabaya pengguna jejaring sosial blackberry messenger. Penelitian ini menggunakan metode penelitian kuantitatif dengan rancangan penelitian korelasional. Partisipan penelitian ini berjumlah 187 mahasiswa yang memiliki akun blackberry messenger serta merupakan pengguna aktif blackberry messenger. Penelitian ini menggunakan instrument skala self esteem dan skala self disclosure yang dianalisis menggunakan korelasi product moment. Hasil analisis uji Product Moment menunjukkan hasil korelasi sebesar 0,315 pada taraf signifikasi $p=0,000(p>0,05)$, artinya menunjukkan bahwa hipotesis "ada hubungan self esteem dengan self disclosure pada mahasiswa Psikologi Universitas Negeri Surabaya pengguna jejaring sosial blackberry messenger" diterima.
\end{abstract}

Kata Kunci: Self esteem, self disclosure, blackberry messenger

Jejaring sosial merupakan salah satu perkembangan teknologi yang memiliki peranan besar dalam memberikan kemudahan bagi manusia untuk berkomunikasi dan bersosialisasi. Social Networking Site $(S N S)$, atau situs jejaring sosial didefinisikan sebagai suatu layanan yang memungkinkan setiap individu untuk membangun hubungan sosial melalui dunia maya.
Situs jejaring sosial digunakan sebagai fasilitas bagi individu untuk menjalin hubungan dengan individu lainnya yang memungkinkan mereka untuk bersamasama membangun atau memperluas jaringan sosial mereka, menunjukkan koneksi seseorang dan memperlihatkan hubungan yang ada antar penggunanya. Situs jejaring sosial memungkinkan peng-

Korespondensi tentang artikel ini dapat dialamatkan kepada Ferdiana S. Prawesti melalui email: ferrdhieana@gmail.com 
gunanya untuk mendefinisikan profil secara online, terhubung dengan individu lain dalam jaringan sosial dunia maya, dapat secara cepat melakukan pemberitahuan tentang suatu kegiatan (notification), dan melakukan pengaturan privasi (Boyd \& Ellison, 2007; Gotta, 2008; Beer, 2008, Dashgupta, 2010).

Kemudahan yang ditawarkan oleh jejaring sosial yang diantaranya dapat digunakan oleh siapapun atau universal tanpa ada perbedaan terhadap kelas atau status sosial serta kebebasan untuk menggunakannya, membuat penggunaan jejaring sosial menjadi trend baru bagi media interaksi dan komunikasi bagi seluruh lapisan masyarakat.Berdasarkan survei APJII (Asosiasi Penyelenggara Jasa Internet Indonesia) pada tahun 2012, 63 juta masyarakat Indonesia terhubung dengan Internet dengan sebanyak $95 \%$ aktivitas populasi itu saat mengakses dunia maya adalah membuka media sosial (Merdeka.com, 2014). Pada akhir tahun 2014 tercatat masyarakat yang menggunakan internet sejumlah 88,1 juta pengguna dengan mayoritas pengguna mulai dari usia 18 hingga 25 tahun (beritasatu.com, 2015). Salah satu jejaring sosial yang saat ini sedang popular dan banyak digunakan di Indonesia adalah Blackberry Messenger (BBM) dengan jumlah persentase pengguna mencapai $79 \%$ dari total pengguna smartphone (teknokompas.com, 2014).

Hasil penelitian dari Krasnova, dkk (2010) mengatakan bahwa motivasi seseorang menggunakan situs jejaring sosial karena merasakan kenyamanan dalam menceritakan informasi pribadinya. Penggunaan jejaring sosial selain untuk membangun maupun memperluas hubungan sosial melalui dunia maya juga berfungsi untuk menjadi media dalam menyampaikan apa yang terjadi saat ini, apa yang dialami dan apa yang dirasakannya semua dapat dituangkan dengan menggunakan salah satu aplikasi yang terdapat dalam jejaring sosial (Weiser, 2001). Aplikasi atau fasilitas yang dimaksud yaitu fasilitas update status. Fasilitas update status adalah fasilitas yang memungkinkan pengguna untuk memposting ide-ide, cerita, aktivitas yang dilakukan, dan hal-hal lain yang berhubungan dengan si pengguna media sosial. Fasilitas update satus ini menjadi sangat popular dikalangan banyak orang dikarenakan fasilitas ini digunakan sebagai media mengekspresikan atau mengungkap diri pengguna jejaring sosial ke publik atau pengguna media sosial lainnya.

Hal ini merupakan salah satu tipe komunikasi dimana informasi diri sendiri (self) yang biasanya disembunyikan dari orang lain kini dikomunikasikan kepada orang lain (Rakhmat, 2005). Devito (2007) mengungkapkan bahwa hal tersebut merupakan self disclosure atau pengungkapan diri yang merupakan jenis komunikasi dimana kita mengungkapkan informasi tentang diri kita sendiri yang secara aktif kita sembunyikan.Boyd dan Heer (2006) mengemukakan bahwa keterbukaan diri dalam jejaring sosial bermanfaat untuk menjadi sarana dalam mempresentasikan identitas diri. Pengguna jejaringsosial akan lebih leluasa mengungkapkan apa yang mereka alami dan apa yangmereka pikirkan tanpa harus bertatap muka.

Fenomena mengungkapkan diri ke jejaring sosial ini terjadi pada seluruh pengguna jejaring sosial. Begitu juga yang terjadi dilapangan, sesuai survey yang dilakukan 15 April 2015 pada mahasiswa Psikologi Universitas Negeri Surabaya ditemukan dari seluruh mahasiswa yang berjumlah 372 mahasiswa menggunakan jejaring sosial selain untuk berkomunikasi juga mengungkapkan dirinya melalui aplikasi update status. Adapun jejaring sosial yang sering atau banyak mereka gunakan yaitu blackberry messenger denganpresentase sebanyak $94 \%$. Pengungkapan diri yang mereka lakukan 
tidak lebih hanya untuk mengekspresikan juga melampiaskan apa yang mereka rasakan. Berbagi cerita, kejadian atau pengalaman yang dialami pada temanteman yang berada di kontak jejaring sosial mereka. Kegiatan mengungkap diri melalui update status ini menjadi rutinitas yang dilakukan setiap hari oleh para mahasiswa ini. Berdasarkan dari penelitian yang dilakukan oleh Stone (1996) dan Turkle (1997) mengemukakan bahwa internet telah mengubah pola interaksi interpersonal sehingga memungkinkan seseorang untuk berbagi pengalaman pribadi kepada orang asing.

Joinson (2004) mengungkapkan bahwa tingkat signifikasi pengungkapan diri lebih tinggi terjadi pada komunikasi melaluiyang termediasi oleh perangkat komputerdaripada dengan komunikasi tatap muka, yang termasuk didalamnya jejaring sosial. Hal ini juga diperkuat oleh pendapat dari Bargh, dkk (2002) yang mengatakan bahwa jenis interaksi melalui jejaring sosial lebih memungkinkan terjadi proses keterbukaan diri dibandingkan dengan interaksi yang terjadi dengan bertatap muka, proses keterbukaan diri di media online lebih sering terjadi karena adanya anonimitas.

Penelitian yang dilakukan Sundar (2013) menemukan bahwa media sosial mengisyaratkantingkat harga diri sang pemilik akun (Kompas.com, 2013; Jpnn.com,2014). Hasil penelitian menunjukkan pengguna media sosial dengan berbagai aktivitasnya di dunia maya menunjukkan gambaran akurat mengenai dirinya sendiri. Pengguna media sosial dengan harga diri rendah cenderung mengkhawatirkan apa yang orang lain posting tentang mereka di jejaring sosial, mereka akan lebih banyak menggunakan waktunya di media sosial (dalam hal ini facebook) dengan memantau konten, menghapus posting yang mendapatkan respons negatif dari orang lain. Pengguna media sosial yang memiliki harga diri lebih tinggi cenderung menghabiskan waktu untuk membangun citra personal di media sosial. Mereka lebih sering memposting mengenai apa yang mereka suka atau tidak suka, opini tentang sesuatu, juga persepsinya tentang berbagai hal (Kompas. com, 2013; Jpnn.com, 2014).

Penelitian yang dilakukan oleh Forest dan Wood (2012) mengenai "When Social Networking Is Not Working: Individuals With Low Self-Esteem Recognize but Do Not Reap the Benefits of Self-Disclosure on Facebook", melibatkan sebanyak 177 pengguna facebook dengan mempertimbangkan postingan pada wallupdate status. Penelitian menunjukkan bahwa individu dengan harga diri rendah lebih banyak mengungkapkan hal-hal yang kurang positif dan lebih banyak mengungkap halhal yang negatif dibanding dengan individu dengan harga diri tinggi. Individu dengan harga diri rendah cenderung lebih banyak mengungkapkan kesedihan, kemarahan, frustrasi, kecemasan, ketakutan, lekas marah, rasa kurang bahagia, dan rasa kurangbersyukur dalam postingan mereka daripada individu dengan harga diri tinggi.

Berdasarkan penelitian-penelitian yang ada terlihat bahwa pengungkapan diri ke media atau jejaring sosial tidak terlepas dari self esteem (harga diri) individu. Velasco (2013) menyatakan bahwa harga diri merupakan salah satu dimensi yang bisa mempengaruhi pengungkapan diri secara online. Hal ini disebabkan oleh perbedaan antara individu dengan harga diri tinggi dan rendah yang paling menonjol adalah ketika berada di publik (Baumeister, dkk, 1989). Individu denganharga diri rendahsangattidak mudah untuk mengungkapkan diri. Penggunaan teknologi untuk menengahi interaksi interpersonal memberikan kesempatan bagi individu dengan harga diri rendah untuk melindungi diri dari umpan balik negatif. Jika dihadapkan dengan situasi yang menimbulkan risiko interpersonal, individu dengan harga diri rendah lebih suka 
menggunakane-mailatau media sosial lain dari pada dengan berkomunikasi tatap muka (Joinson, 2004).

Harga diri merupakan evaluasi diri yang dibuat individu terhadap dirinya dalam rentang positif sampai negatif (Baron dan Byrne, 2004). Menurut Coopersmith (Burns, 1993) harga diri mengacu kepada evaluasi seseorang tentang dirinya sendiri baik positif maupun negative dan menunjukkan tingkat dimana individu meyakini dirinya sendiri sebagai individu yang mampu, penting, berhasil, dan berharga. Individu dengan harga diri yang tinggi cenderung mengadopsi strategi peningkatan diri, sementara individu dengan harga diri yang rendah cenderung untuk mengadopsi strategi perlindungan diri. Individu dengan harga diri yang tinggi cenderung mengambil risiko untuk diri meningkatkan diri, sementara individu dengan harga diri rendah akan melindungi dirinya dan tidak mengambil risiko penghinaan publik, meskipun keberhasilan akan bermanfaat dalam meningkatkan nilai diri mereka (Baumeister, dkk, 1989).

Menurut Michener dan DeLamater (1999) individu dengan harga diri tinggi bersikap asertif, terbuka, dan memiliki kepercayaan terhadap dirinya. Sikap asertif tersebut memungkinkan mereka untuk dapat menyatakan diri apa adanya sehingga pengungkapan diri yang dilakukan bukan sebagai topeng untuk menutupi kelemahannya.Individu dengan harga diri rendah menunjukkan perilaku yang menghambat pengungkapan diri. Menurut Burns (1993), individu tersebut cenderung tidak dapat mengekspresikan diri serta mengalami kesulitan dalam menunjukkan diri, perasaan, dan pikirannya yang disebabkan oleh adanya penilaian yang negative terhadap diri sendiri maupun orang lain serta menganggap bahwa hubungan dengan orang lain merupakan sebuah ancaman.

\section{Metode}

Penelitian ini menggunakan metode penelitian kuantitatif dengan rancangan penelitian korelasional untuk mengungkap hubungan self esteem dengan self disclosure pada mahasiswa Psikologi Universitas Negeri Surabaya pengguna jejaring sosial blackberry messenger.

Penelitian ini melibatkan 187 mahasiswa Psikologi Universitas Negeri Surabaya angkatan 2011-2014. Teknik pengambilan sampel penelitian dilakukan dengan teknik accidental sampling. Penelitian ini dilaksanakan di Prodi Psikologi Universitas Negeri Surabaya.

Instrumen penelitian yang digunakan adalah skala self esteem dan skala self disclosure dengan menggunakan model skala likert. Skala self esteem pada penelitian ini disusun berdasarkan aspekaspek self esteem yang dikemukakan oleh Coopersmith (1967). Skala self disclosure pada penelitian ini disusun berdasarkan komponen-komponen self disclosure yang dikemukakan oleh Devito (1997).

Penelitian ini menggunakan teknik analisis data product moment correlation yang bertujuan untuk mengetahui hubungan variabel bebas dengan varibel terikat. Analisis dilakukan dengan menggunakan bantuan program SPSS versi 17.00 for windows.

\section{Hasil dan Pembahasan}

Berdasarkan analisis data yang dilakukan dengan menggunakan uji korelasi product moment diketahui bahwa ada hubungan positif antara self esteem dengan self disclosure pada mahasiswa Psikologi Universitas Negeri Surabaya pengguna jejaring sosial blackberry messenger. Hal ini dibuktikan dari hasil statistik yang menunjukkan bahwa nilai koefisien korelasi dari kedua variabel sebesar 0,315 dan nilai signifikasi atau pro- 
babilitasnya sebesar $(p)=0,000(p<0,05)$.

Berdasarkan hasil pengolahan data mengenai hubungan self esteemdengan self disclosure mahasiswa Psikologi Univesitas Negeri Surabaya melalui blackberry messenger, menyatakan bahwa hipotesis yang ada diterima. Hal ini dibuktikan dengan hasil pengolahan data yang menunjukkan nilai signifikasi sebesar 0.000 dan nilai hubungan sebesar 0.315 yang menunjukkan bahwa variabel self esteem hanya berkontribusi mempengaruhi variabel self disclosure sebanyak 31,5\%, sedangkan sisanya dipengaruhi oleh faktor lain. Faktor-faktor lain yang diduga turut mempengaruhi self disclosure (pengungkapan diri) menurut Devito (1997) antara lain resiprositas (timbal balik), ukuran khalayak, topik bahasan, hubungan kedekatan (keakraban) serta norma-norma budaya menurut Velasco (2013).

Penyebab hubungan self esteem (harga diri) dengan self disclosure (pengungkapan diri) pada mahasiswa Psikologi Universitas Negeri Surabaya yang lemah antara lain dipengaruhi oleh faktor lain seperti kurang adanya norma resiprositas (timbal balik) dalam proses self disclosure (pengungkapan diri) yang dilakukan oleh mahasiswa Psikologi Universitas Negeri Surabaya. Mahasiswa Psikologi Universitas Negeri Surabaya hanya sekedar melakukan self disclosure (pengungkapan diri) tanpa adanya timbal balik seperti memberi komentar, membalas komentar maupun respon suka atau tidak dengan menggunakan stiker atau emoticon dari teman-teman. Hal ini didukung oleh penelitian dari Moon (2000) yang mengatakan bahwa individu lebih banyak mengungkapkan diri dalam keadaan timbal balik: ketika teman-teman memiliki banyak kesamaan dengan karakteristik mereka, maka individu akan lebih mengungkapkan informasi pribadinya.

Lemahnya hubungan self esteem (harga diri) dengan self disclosure (pengungkapan diri) mahasiswa Psikologi
Univesitas Negeri Surabaya melalui blackberry messenger juga bisa di sebabkan oleh ukuran khalayak, sebab pada penelitian ini diketahui bahwa mahasiswa psikologi Universitas Negeri Surabaya lebih cenderung melakukan self disclosure ke semua kontak blackberry messenger yang ada daripada hanya ke beberapa orang tertentu atau melalui group chat. Hal ini sesuai dengan Devito (2011) yang mengungkapkan bahwa proses terjadinya self disclosure lebih besar kemungkinannya terjadi dalam komunitas dengan kelompok atau khalayak kecil.

Topik bahasan juga faktor yang turut berpengaruh terhadap lemahnya hubungan self esteem (harga diri) dengan self disclosure (pengungkapan diri) mahasiswa Psikologi Universitas Negeri Surabaya melalui blackberry messenger. Devito (2011) mengungkapkan bahwa topik bahasan mempengaruhi self disclosure (pengungkapan diri) individu, jika topik bahasan lawan komunikasi individu maka akan lebih besar kemungkinan terjadi self disclosure (pengungkapan diri). Berdasarkan hasil penelitian, diketahui bahwa sebagian besar mahasiswa enggan melakukan self disclosure (pengungkapan diri) dikarenakan topik yang dibahas kurang tepat, kurang menarik dan sensitive terutama mengenai topic masalah pribadi, rencana masa depan, keadaan keluarga, serta perasaan mahasiswa sendiri yang hanya bisa diungkapkan ke orang-orang tertentu yang ada dikontak blackberry messenger masing-masing. Hal ini juga sesuai dengan hubungan kedekatan (keakraban) dengan lawan komunikasi sebagaimana Devito (2011) menyatakan bahwa semakin akrab hubungan seseorang dengan orang lain, semakin terbuka ia kepada orang tersebut. Sehingga jika hubungan yang dimiliki mahasiswa dengan teman-teman atau beberapa teman-teman yang ada di kontak blackberry messenger tergolong akrab maka mahasiswa akan 
lebih terbuka begitu juga dengan topik bahasannya akan semakin luas dan dalam.

Hubungan self esteem (harga diri) dengan self disclosure (pengungkapan diri) mahasiswa Psikologi Universitas Negeri Surabaya yang lemah juga turut dipengaruhi oleh adanya norma-norma budaya atau etika yang berlaku, yang menganggap bahwa orang yang terlalu banyak menceritakan segala hal tentang dirinya terutama tentang kelebihan dan keberhasilannya, adalah orang yang sombong dan suka pamer. Norma-norma budaya, pada penelitian lintas budaya dalam pengungkapan diri menemukan bahwa norma-norma budaya masyarakat dapat mempengaruhi apa yang diungkapkan oleh individu (Chen, 1995; Diaz, dkk, 2003; Dia, dkk, 2010). Individu yang demikian akan kurang mendapat penerimaan dari lingkungan, bahkan cenderung dijauhi. Hal ini sejalan dengan Rosenfeld (Tubbs dan Moss, 1996) yang mengatakan bahwa seseorang lebih memilih tidak menyatakan diri kepada orang lain karena takut mendapat citra buruk, dianggap pamer dihadapan umum, dan takut mendapat penolakan.

Hasil penelitian ini sesuai didukung oleh Bargh,dkk (2002) yang mengatakan bahwa jenis interaksi melalui jejaring sosial lebih memungkinkan terjadi proses keterbukaan diri dibandingkan dengan interaksi yang terjadi dengan bertatap muka. Hasil penelitian ini juga sejalan dengan pendapat dari Krasnova, dkk (2010) yang menyatakan bahwa selain digunakan untuk membangun hubungan pertemanan yang baru, menjalin komunikasi kembali dengan teman yang lama, menampilkan profil-profil dan informasi sesuai dengan gambaran yang dipikirkan dan diinginkan, jejaring sosial juga tak luput menjadi wadah bagi individu untuk menceritakan informasi pribadinya.

Pengungkapan diri dapat dilakukan jika individu mau membuka daerah tersembunyi dengan cara memberikan informasi yang bersifat pribadi dan rahasia kepada orang lain. Kesediaan membuka diri tersebut berawal dari adanya penilaian positif terhadap orang lain (Sari, dkk, 2006). Penilaian terhadap orang lain tersebut bermula dari kesediaan menerima diri sendiri dan memiliki penilaian positif terhadap diri sendiri. penilaian terhadap diri sendiri merupakan makna dari harga diri, sebagaimana dinyatakan oleh Buss (1995). Semakin berkembangnya kemajuan teknologi yang ada maka penggunaan teknologi untuk menengahi interaksi interpersonal memberikan kesempatan bagi individu dengan harga diri rendah untuk melindungi diri dari umpan balik negatif. Hal ini diperkuat oleh Joinson (2004) yang menyatakan jika dihadapkan dengan situasi yang menimbulkan risiko interpersonal, individu dengan harga diri rendah lebih suka menggunakane-mailatau media sosial lain dari pada dengan berkomunikasi tatap muka.

Harga diri yang dimiliki individu memiliki karakteristik tertentu yang mempengaruhi cara berinteraksi dengan orang lain. Individu dengan harga diri rendah menurut Burns (1993) cenderung merasa terasing, tidak dihargai, dan tidak dapat mengekspresikan diri. Hasil penelitian Murray, dkk (2000) juga menunjukkan bahwa mereka menjaga jarak dalam berhubungan dengan orang lain,dan menganggap orang lain kurang ramah. Kesalahan dalam menilai orang lain dengan menganggap orang lain kurang ramah tersebut merupakan akibat dari anggapan bahwa orang lain tidak menyukainya (Buss, 1995).

Adanya perasaan tidak disukai orang lain semakin membuat individu dengan harga diri rendah enggan mengungkapkan diri karena pengungkapan diri dapat terjadi jika target dipersepsikan menunjukkan niat baik dan dapat dipercaya (Jourard, 1964). Rosenberg dan Wylie mengatakan individu dengan harga diri tinggi menunjukkan ciri yang berlawanan dari individu dengan 
harga diri rendah, karena mereka aktif dan dapat merasa nyaman dalam berinteraksi (Michener dan DeLamater, 1999). Mathews (1993) menambahkan bahwa individu dengan harga diri tinggi dapat menerima dirinya dan mengijinkan orang lain mengetahui apa yang dipikirkan dan dirasakan. Kesediaan membuka diri kepada orang lain tersebut merupakan indikasi dari pengungkapan diri yang tinggi, dengan demikian nampak bahwa harga diri tinggi menyebabkan pengungkapan diri yang tinggi pula. Hasil penelitian ini juga didukung oleh penelitian oleh Sari, dkk (2006) yang menyatakan bahwa terdapat hubungan positif antara harga diri dengan pengungkapan diri yang berarti semakin tinggi harga diri, maka semakin tinggi pula pengungkapan diri.

\section{Simpulan}

Berdasarkan hasil penelitian tentang hubungan self esteem dengan self disclosure pada mahasiswa psikologi Universitas Negeri Surabayapengguna jejaring sosial blackberry messenger, didapatkan hasil yang positif dan signifikan. Hal ini berarti semakin tinggi tingkat self esteem individu maka semakin tinggi tingkat self disclosurenyadan sebaliknya, semakin tinggi tingkat self disclosure yang dimiliki individu maka semakin tinggi juga tingkat self esteem individu tersebut. Jadi didapatkan simpulan bahwa terdapat hubungan antara self esteem dengan self disclosure pengguna jejaring sosial blackberry messenger pada mahasiswa psikologi Universitas Negeri Surabaya.

\section{Daftar Pustaka}

Bargh, J. A., McKenna, K. Y., \& Fitzsimons, G. M. (2002). Can you see the real me? Activation and expression of the "true self" on the Internet. Journal of social issues, 58(1), 33-48. Online. http://smg.media.mit.edu. Diakses 31 Maret 2015.

Baumeister, R.F., Tice, D.M., \& Hutton, D.G. (1989). Self-presentational motivations and personality differences in self-esteem. Journal of Personality 57:547-579. Online. http://onlinelibrary.wiley.com,

Diakses 25 Maret 2015.

Boyd, D.M., \& Ellison, N. (2007). Social Network Sites: Definition, History, and Scholarship. Journal of Computer-Mediated

Communication, 13 (1), 1-11. Online. http://jcmc.indiana.edu, Diakses 18 Maret 2015.
Burns, R.B. (1993). Konsep Diri Teori, Pengukuran, Perkembangan dan Perilaku. Alih Bahasa: Eddy. Jakarta: Penerbit Arcan.

Buss, A. H. (1995). Personality: Temperament, Social Behavior and The Self. Boston: Allyn and Bacon.

Devito, Joseph. (1997). Komunikasi Antar Manusia. Edisi Ke-5. Jakarta: Professional Books.

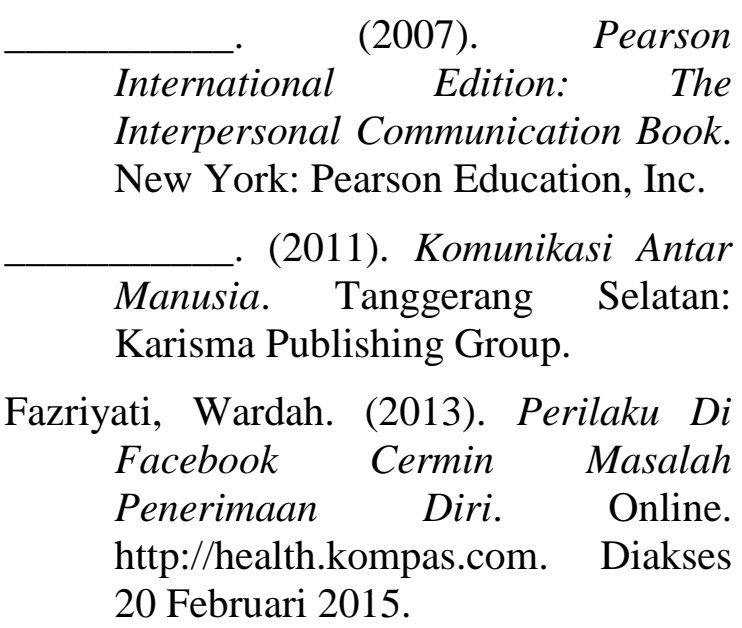


Forest, A. L.,\& Wood Joanne V. (2012). When Social Networking Is Not Working: Individuals With Low SelfEsteem Recognize but Do Not Reap the Benefits of Self-Disclosure on Facebook.

Online. http://www.centenary.edu. Diakses 17 Maret 2015.

Fny. (2014). Kepribadian Bisa Dilihat Dari Postingan Facebook. Online. http://www.jpnn.com. Diakses 20 Februari 2015.

Joinson, A. N. (2004). Self-esteem, interpersonal risk, and preference for e-mail to face-to face communication. CyberPsychology \& Behavior, 7(4), 472-478. UK: Mary Ann Liebert, Inc.

Jourard, M.S. (1964). The Transparent Self: Self Disclosure and WellBeing. New York: Van Nostrand Reinhold Company.

Kure, Emanuel. (2015). Mayoritas Netizen di Indonesia Berusia 18-25 Tahun. Online. http://www.beritasatu.com. Diakses 20 Maret 2015.

Krasnova, H., Spiekermann, S., Koroleva, K., \& Hildebrand, T. (2010). Online social networks: Why we disclose. Journal of Information Technology, 25(2), 109-125. Online. http://www.palgrave-journals.com. Diakses 17 Maret 2015.

Matthews, D.W. (1993). Acceptance of Self and Others. Online. http://www.ces.ncsu.edu. Diakses 3 Maret 2015.

Michener, H.A \& DeLamater, J.D. (1999). Social Psychology. Fourth Edition. Orlando: Harcourt Brace College Publishers.

Mohamad, Ardyan. (2013). Di 5 Media Sosial ini orang Indonesia Pengguna Terbesar Dunia. Online. http://www.merdeka.com, Diakses 20 Februari 2015.

Moon, Y. (2000). Intimate exchanges: Using computers to elicit selfdisclosure from consumers. Journal of Consumer Research, 26(4), 323339. Chicago: University of Chicago Press.

Sari Retno P., A. Tri Rejeki, \& M. Achmad Mujab. (2006). Pengungkapan Diri Mahasiswa Tahun Pertama Universitas Diponegoro Ditinjau Dari Jenis Kelamin Dan Harga Diri. Jurnal Psikologi Universitas Diponegoro, 3(2). Online. http://ejournal.undip.ac.id. Diakses 4 Maret 2015.

Tubbs, Stewart L. \& Moss, Sylvia. (1996). Human Communication: PrinsipPrinsip Dasar. Bandung: Remaja Rosdakarya.

Velasco-Martin, J. (2013). Exploring Self Disclosure In Online Social Network. School Of Information and Library Science. Online. http://www.cdr.lib.unc.edu. Diakses 23 Maret 2015. 